\title{
PENGEMBANGAN MULTIMEDIA PEMBELAJARAN INTERAKTIF BERORIENTASI PENDIDIKAN KARAKTER MATA PELAJARAN BAHASA BALI
}

\author{
I Gusti Ayu Agung Sri Sasmita Dewi \\ Program Studi Teknologi PendidikanUniversitas Pendidikan Ganesha \\ sri.sasmita.dewi@undiksha.ac.id
}

I Gde Wawan Sudatha

Program Studi Teknologi PendidikanUniversitas Pendidikan Ganesha igdewawans@undiksha.ac.id

\author{
Adrianus I Wayan Ilia Yuda Sukmana \\ Program Studi Teknologi PendidikanUniversitas Pendidikan Ganesha \\ aiwiy-sukmana@undiksha.ac.id
}

\begin{abstract}
Abstrak
Penelitian ini dilatar belakangi oleh permasalahan yaitu rendahnya hasil belajar Bahasa Bali. Penelitian ini bertujuan untuk (1)mengetahui proses pengembangan multimedia pembelajaran interaktif berorientasi pendidikan karakter (2)mengetahui validitas dari multimedia pembelajaran interaktif berorientasi pendidikan karakter (3)mengetahui efektivitas multimedia yang dikembangkan. Penelitian ini adalah penelitian pengembangan. Model pengembangan yang digunakan adalah model Hannafin and Peck.Data yang dikumpulkan dalam penelitian ini adalah data kuantitatif berupa skor pretest, posttest dan kualitatif berupa saran, masukan dan kritik perbaikan media.Metode pengumpulan data yang digunakan adalah metode observasi, pencatatan dokumen, kuesioner dan tes.Hasil penelitian adalah sebagai berikut. (1) pengembangan multimedia dengan model Hannafin and Peck meliputi tiga tahapan yaitu penilaian kebutuhan, desain, pengembangan dan implementasi. (2) multimedia pembelajaran interaktif berorientasi pendidikan karakter yang dikembangkan valid dengan: (a) hasil review ahli isi mata pelajaran menunjukkan multimedia berpredikat sangat baik (90\%), (b) hasil review ahli multimedia menunjukkan produk berpredikat sangat baik (96\%), (c) hasil review ahli desain pembelajaran menunjukkan multimedia berpredikat sangat baik $(90,7 \%)$, (d) hasil uji coba perorangan, uji coba kelompok kecil dan uji coba lapangan menunjukkan multimedia berpredikat sangat baik $(93,7 \%)$, (94,0\%) dan $(93,9 \%)$. (3) multimedia yang dikembangkan efektif meningkatkan hasil belajar Bahasa Bali. Ini berarti bahwa multimedia terbukti efektif secara signifikan dapat meningkatkan hasil belajar Bahasa Bali.
\end{abstract}

Kata Kunci :multimedia, pendidikan karakter, pengembangan

\begin{abstract}
This research is motivated by the problem of the low learning outcomes of Balinese Language. This study aims to (1) find out the developing process of education-oriented interactive learning multimedia characters (2) find out the validity of interactive learning of multimedia educational oriented to character education(3) find out the effectiveness of multimedia developed. This research is development research. The development model used is the Hannafin and Peck model. The data collected in this study are quantitative data in the form of pretest, posttest and qualitative scores in the form of suggestions, input and criticism of media improvement. The method of data collection used is the observation method, recording documents, questionnaires and tests. The results of the study are (1) multimedia development with the Hannafin and Peck model includes three stages, namely needs assessment, design, development and implementation.(2) interactive learning of multimedia oriented character education developed validly by: (a) the results of the subject matter experts review showed that multimedia had a very good predicate (90\%), (b) the results of multimedia experts showed that the product was very good (96\%), (c) the results of the learning design experts review showed that multimedia had a very good predicate $(90.7 \%),(d)$ the results of individual trials, small group trials and field trials showed that multimedia was very good (93.7\%),(94,0\%)and(93.9\%). (3)multimedia developed effectively improves the results of learning Balinese Language. This means that multimedia has proven to be effective in significantly improving the learning outcomes of Balinese Language.
\end{abstract}

Keywords:character education, development, multimedia 


\section{Pendahuluan}

Teknologi Informasi dan Komunikasi dengan kemampuan menyalurkan informasi secara cepat telah memberikan manfaat yang sangat berarti dalam kehidupan manusia.Dengan hadirnya Teknologi Infomasi dan Komunikasi (TIK), orang-orang yang berada di seluruh dunia dapat saling bertukar informasi dan berinteraksi dengan cepat dan efisien, tidak tergantung pada lokasi mereka ataupun perbedaan bahasa yang mereka gunakan sehari-hari.Teknologi yang berkembang sangat pesat ini membawa dampak yang luar biasa pada berbagai sektor kehidupan seperti bisnis, hiburan, dan pendidikan.Pengaruh pada bidang pendidikan sangat jelas kita rasakan.Disini pendidikan berperan penting dalam mencerdaskan bangsa.Saat ini paradigma pendidikan telah bergeser dari paradigma behavioristik menuju konstruktivistik. Wonorahardjo (dalam Utami dkk, 2009) mengatakan pada dasarnya pendekatan konstruktivistik menekankan proses membangun sendiri konsep-konsep yang dipelajari oleh siswa (student oriented).

Pandangan konstruktivistik meyakini bahwa siswa merespon pengalaman-pengalaman pancaindera dengan mengkonstruksi suatu skema atau struktur kognitif ke otak. Pengetahuan atau pengertian siswa diperoleh sebagai akibat dari proses konstruksi (aktif) yang berlangsung terus menerus dengan cara mengatur, menyusun dan menata ulang pengalaman yang dikaitkan dengan struktur kognitif yang telah dimiliki sehingga struktur kognitif tersebut sedikit demi sedikit dimodifikasi dan dikembangkan.) "Tujuan pendidikan disetiap jenjang adalah meningkatkan pengetahuan siswa untuk melanjutkan pendidikan pada jenjang yang lebih tinggi dan mengembangkan diri sejalan dengan perkembangan ilmu pengetahuan, teknologi dan kesenian, serta meningkatkan kemampuan siswa" (Paul Suparno, dkk 2002 : 67). Untuk meningkatkan kemampuan siswa dalam proses pembelajaran tidak hanya melibatkan guru, diharapkan siswa ikut aktif berinteraksi dengan sumber belajar. Dalam metodologi pengajaran ada dua aspek yang paling menonjol yakni metode mengajar dan media pembelajaran sebagai alat bantu untuk mengajar (Sudjana, dalam Ramadhan, 2013).

Adakalanya proses penafsiran pembelajaran tersebut berhasil dan mengalami kegagalan. Menurut Sadiman dalam Sulistyono 2013 , kegagalan ini bisa saja disebabkan oleh beberapa faktor, misalnya adanya hambatan psikologis (menyangkut minat, sikap, kepercayaan, inteligensi, dan pengetahuan), hambatan fisik berupa kelelahan,keterbatasan daya alat indera, dan kondisi kesehatan penerima pesan. Faktor lain yang juga berpengaruh adalah hambatan kultural (berupa perbedaan adat istiadat, norma-norma sosial, kepercayaan dan nilai-nilai panutan), dan hambatan lingkungan yaitu hambatan yang ditimbulkan oleh situasi dan kondisi keadaan sekitar. Karakter siswa juga menjadi hambatan dalam pendidikan, dapat kita lihat pada berita-berita yang tayang ditelevisi saat ini, marak terjadi tindak kekerasan di lingkungan sekolah, seperti bully di karangan remaja, tawuran, ketidakjuuran, siswa yang tidak hormat kepada guru. Perilaku-perilaku seperti itu menunjukan bahwa bangsa ini telah terbelit oleh rendahnya moral, akhlak atau karakter (Zuchdi dalan Rachmah, 2013).Untuk mengatasi kemungkinan-kemungkinan hambatan-hambatan yang terjadi selama proses penafsiran dan agar pembelajaran berlangsung secara efektif, maka penyampaian pesan atau isi materi dibantu dengan menggunakan media pembelajaran yang dapat menanamkan pendidikan karakter.

Berdasarkan hasil observasi dan wawancara yang dilakukan dengan guru pengajar Bahasa Bali kelas V di SD Negeri 1 Angantaka, diperoleh informasi mengenai proses pembelajaran yang selama ini berlangsung. Guru lebih sering menggunakan metode ceramah daripada media pembelajaran kurang menarik, menjadikan siswa kurang tertarik untuk belajar. Kemudian tersedianya fasilitas seperti LCD proyektor yang belum digunakan secara maksimal. Dengan multimedia pembelajaran interaktif diharapkan dapat mempermudah guru dalam menyampaikan materi pembelajaran membantu siswa dalam proses belajarnya, sehingga siswa dapat berkomunikasi secara langsung maupun tidak langsung, baik itu dalam pembelajaran di kelas maupun di luar kelas.

Berdasarkan paparan tersebut, maka dalam penelitian ini dicoba untuk mengembangkan multimedia pembelajarn interaktif berorientasi pendidikan karakter pada mata pelajaran Bahasa Bali kelas V Di SD Negeri 1 Angantaka Tahun Pelajaran 2018/2019. Sejalan dengan pemaparan di atas rumusan masalah pada penelitian ini adalah sebagai berikut: (1) bagaimana proses pengembangan multimedia pembelajaran interaktif berorientasi pendidikan karakter pada mata pelajaran Bahasa Bali kelas V Tahun pelajaran 2018/2019 di SD Negeri 1 Angantaka?, (2) bagaimana validitas dari multimedia pembelajaran interaktif berorientasi pendidikan karakter pada mata pelajaran Bahasa Bali kelas V Tahun pelajaran 2018/2019 di SD Negeri 1 Angantaka?, (3) apakah multimedia pembelajaran interaktif berorientasi pendidikan karakter dapat meningkatkan hasil belajar mata pelajaran Bahasa Bali kelas V Tahun pelajaran 2018/2019 di SD Negeri 1 Angantaka?.

Berdasarkan rumusan masalah, adapun tujuan yang ingin dicapai dalam penelitian ini yaitu: (1) untuk mengetahui proses pengembangan multimedia pembelajaran interaktif berorientasi pendidikan karakter pada mata pelajaran Bahasa Bali kelas V Tahun pelajaran 2018/2019 di SD Negeri 1 Angantaka, (2) untuk mengetahui validitas dari multimedia pembelajaran interaktif berorientasi pendidikan karakter pada mata pelajaran Bahasa Bali kelas V Tahun pelajaran 2018/2019 di SD Negeri 1 Angantaka, (3) untuk mengetahui efektivitas pengembangan multimedia pembelajaran interaktif berorientasi pendidikan karakter pada mata pelajaran Bahasa Bali kelas V Tahun pelajaran 2018/2019 di SD Negeri 1 Angantaka. 


\section{Metode}

Dalam penelitian ini peneliti menggunakan model pengembangan Hannafin dan Peck. Pemilihan model Hannafin dan Peck didasarkan atas pertimbangan bahwa model ini berorientasi produk pembelajaran. Di samping itu model Hannafin dan Peck merupakan model desain pembelajaran yang penyajiannya dilakukan secara sederhana, sehingga tidak memerlukan waktu lama (Kurniawan, 2018). Model Hannafin and Peck juga merupakan model yang terstruktur dan sistematik melibatkan evaluasi dan revisi di setiap tahapnya.

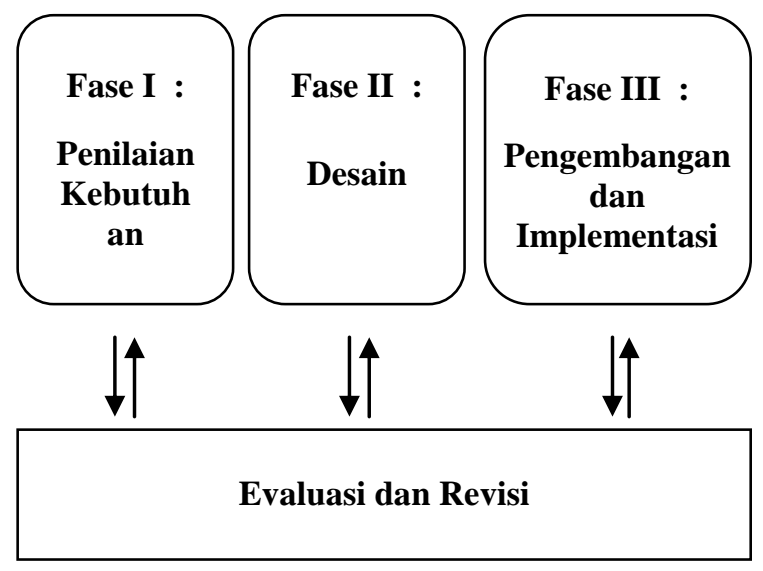

Sumber : Mahadewi dan Yuda 2015

Gambar 1. Model Hannafin and Peck

Menurut Hannafin and Peck "model Hannafin and Peck terdiri atas tiga langkah, yaitu penilaian kebutuhan (need assessment), desain (design), pengembangan dan implementasi (development \& implementation), serta dalam setiap tahap melalui proses evaluasi dan revisi (Tegeh, dkk. 2014:2). Subjek penelitian yaitu seluruh siswa kelas VA SD Negeri 1 Angantaka. Subjek validitas media uji coba perorangan yaitu 3 orang dengan hasil belajar tinggi, sedang dan rendah. Uji coba kelompok kecil 9 orang dengan masingmasing 3 orang hasil belajar tinggi, 3 orang hasil belajar sedang dan 3 orang hasil belajar rendah dan uji coba lapangan.

Objek Penelitian ini adalah hasil belajar Bahasa Bali siswa kelas VA SD Negeri 1 Angantaka. Penelitian ini menggunakan tiga metode pengumpulan data untuk menjawab permasalahan mengenai proses pengembangan multimedia pembelajaran interaktif, validitas multimedia pembelajaran interaktif serta efektivitas multimedia pembelajaran interaktif yaitu, metode pencatatan dokumen, kuesioner/angket dan tes. Instrumen yang digunakan, lembar pencatatan dokumen, lembar kuisioner dan tes pilihan ganda.Validitas pengembangan multimedia pembelajaran interaktif dilakukan dengan menguji produk pada ahli isi mata pelajaran, ahli desain pembelajaran ahli media pembelajaran, uji coba perorangan, kelompok kecil dan lapangan.Dalam penelitian pengembangan ini digunakan tiga teknik analisis data, yaitu teknik analisis deksriptif kualitatif, teknik analisis deskriptif kuantitatif, dan teknik analisis statistik inferensial (uji-t).Sebelum melakukan uji hipotesis (uji-t berkorelasi) dilakukan uji prasyarat (uji normalitas dan homogenitas).Uji normalitas dilakukan untuk mengetahui apakah sebaran skor pada setiap variabel berdistribusi normal atau tidak, untuk itu dapat digunakan rumus Liliefors.

Menurut Koyan (2012: 108) adapun cara yang dapat dilakukan untuk menguji normalitas suatu data dengan teknik liliefors.Jika L0 <Lt, maka H0 diterima, sehingga dapat disimpulkan bahwa sampel berasal dari populasi yang berdistribusi normal. Kemudian uji homogenitas, uji homogenitas ini dilakukan untuk mencari tingkat kehomogenan secara dua pihak yang diambil dari kelompok-kelompok data terpisah dari satu sampel.Untuk menguji homogenitas varians data sampel digunakan uji Fisher (F).Jika $F$ hitung $<$ F tabel, maka kedua kelompok data homogen.Sebaliknya, jika $\mathrm{F}$ hitung > F tabel, maka kedua kelompok data tidak homogen (heterogen) (Agung, 2015:76).Teknik analisis yang digunakan untuk pengujian hipotesis adalah teknik analisis uji-t.

\section{Hasil dan Pembahasan}

Hasil penelitian dibahas tiga hal pokok, yaitu (1) proses pengembangan multimedia pembelajaran interaktif (2) validitas multimedia pembelajaran interaktif, (3) efektivitas multimedia pembelajaran interaktif. Penilaian kebutuhan dilakukan sebagai tahapan awal dalam mengembangkan multimedia pembelajaran interaktif.Tahap analisis kebutuhan ini dilakukan melalui wawancara dengan guru mata pelajaran Bahasa Bali di 
SD Negeri 1 Angantaka. Berdasarkan hasil wawancara diketahui bahwa permasalahan yang dihadapi selama proses pembelajaran yaitu guru lebih sering menggunakan metode ceramah daripada media pembelajaran kurang menarik, menjadikan siswa kurang tertarik untuk belajar sehingga menyebabkan nilai belajar siswa cenderung rendah.

Pengembangan multimedia pembelajaran interaktif dilakukan dengan memilih dan menetapkan perangkat lunak/software yang digunakan untuk mengembangkan multimedia pembelajaran interaktif, selanjutnya mendesain flowchart dan storyboard multimedia interaktif, kemudian menyusun instrument, menyusun kisi-kisi butir soal, dan menyusun RPP.Dalam pengembangan/ mengimplementasikan multimedia pembelajaran interaktif, pengembang dituntut untuk mengaplikasikan keterampilan yang dimiliki sehingga multimedia pembelajaran interaktif dapat dikembangkan sesuai dengan desain yang telah dirancang.

Tahap berikutnya yakni tahap penggunaan produk oleh pengguna. Uji Ahli Isi Mata Pelajaran. Produk multimedia pembelajaran interaktif dinilai oleh seorang ahli isi sekaligus sebagai guru mata pelajaran Bahasa Bali di SD Negeri 1 Angantaka.Berdasarkan hasil penilaian dari ahli isi mata pelajaran, setelah dikonversikan dengan tabel konversi, persentase tingkat pencapaiannya sebesar $90 \%$ berada pada kualifikasi sangat baik. Uji Ahli Desain Pembelajaran. Produk multimedia pembelajaran interaktif ini diujikan kepada seorang ahli desain pembelajaran di program studi Teknologi Pendidikan. Berdasarkan hasil penilai dari ahli desain pembelajaran, setelah dikonversikan dengan tabel konversi persentase tingkat pencapaiannya sebesar 90,7\% berada pada kualifikasi sangat baik. Uji Ahli Media Pembelajaran diujikan kepada seorang ahli media di program studi Teknologi Pendidikan. Berdasarkan hasil penilaian dari ahli media, setelah dikonversikan dengan tabel konversi, persentase tingkat pencapaiannya sebesar $96 \%$.

Tabel 1. Hasil Uji Validitas Produk

(Sumber Data: Hasil Analisis Instrumen, 2019)

\begin{tabular}{lcl}
\hline \multicolumn{1}{c}{ Subjek Uji Coba Multimedia } & Hasil Validitas \\
Interaktif & $(\boldsymbol{\%})$ & Keterangan \\
\hline Ahli isi mata pelajaran & 90,0 & Sangat baik \\
Ahli desain pembelajaran & 90,7 & Sangat baik \\
Ahli media pembelajaran & 96,0 & Sangat baik \\
Uji coba perorangan & 93,7 & Sangat baik \\
Uji coba kelompok kecil & 94,0 & Sangat baik \\
Uji coba lapangan & 93,9 & Sangat baik \\
\hline
\end{tabular}

Uji Coba Perorangan. Sebagai subjek dari uji coba perorangan ini adalah siswa kelas VA SD Negeri 1 Angantaka berjumlah 3 (tiga) orang dengan hasil penilaian rerata persentase 93,7\%. Rerata persentase 93,7\% ini berada pada kualifikasi sangat baik. Uji Coba Kelompok Kecil berjumlah 9(sembilan) orang dengan hasil penilaian rerata persentase $94,0 \%$. Rerata persentase $94,0 \%$ ini berada pada kualifikasi sangat baik.Uji Coba Lapangan berjumlah 21 (dua puluh satu) orang dengan hasil penilaian rerata persentase 93,95\%. Rerata persentase 93,95\% ini beradapada kualifikasi sangat baik. Revisi pengembangan produk. Dalam pengembangan produk multimedia pembelajaran interaktif ini melalui enam tahapan yaitu (1) ahli isi mata pelajaran, (2) ahli media pembelajaran, (3) ahli desain pembelajaran, (4) uji coba perorangan, (5) uji coba kelompok kecil, (6) uji coba lapangan. Dalam ke enam tahapan revisi tersebut, ada sedikit revisi dan ada beberapa masukan serta saran dari para ahli dan subjek uji coba.

Berdasarkan nilai pretest dan posttest 21 orang siswa tersebut, maka dilakukan uji-t untuk sampel berkorelasi. Rata-rata nilai pretest adalah 46,2 dan rata-rata nilai posttest adalah 81,9 . Peningkatan rata-rata nilai siswa ini juga dapat dilihat berdasarkan jawaban- jawaban siswa saat menjawab tes. Sebagian besar jawaban siswa yang salah saat pretest dalam menempuh posttest jawaban tersebut menjadi benar. Ini berarti media multimedia pembelajaran interaktif berorientasi pendidikan karakter efektif dalam membantu siswa dalam meningkatkan hasil belajar siswa pada mata pelajaran Bahasa Bali tahun pelajaran 2018/2019. Hal ini didukung oleh teori yang mengatakan keuntungan dalam mendayagunakan multimedia dalam pembelajaran yaitu "membangkitkan motivasi kepada siswa dalam belajar, kemampuan daya rekamnya memungkinkan pengajaran individual bisa dilaksanakan" (Nana Sudjana dan Ahmad Rivai, dalam Sudatha dan Tegeh, 2007:23) . selaras dengan pendapat tersebut, Windu (2016) juga menyatakan manfaat multimedia interaktif yaitu "meningkatkan motivasi kreativitas keterampilan gairah belajar, memperjelas dan mempermudah penyajian pesan, mengatasi keterbatasan waktu, ruang dan daya indera baik siswa maupun guru, mengembangkan kemampuan siswa dalam berinteraksi langsung dengan lingkungan dan sumber belajar, memungkinkan siswa untuk belajar secara mandiri sesuai kemampuan dan minatnya”.

Pembelajaran dikatakan sebagai suatu sistem karena pembelajaran adalah kegiatan yang bertujuan, yaitu membelajarkan siswa. Komponen- komponen pembelajaran meliputi tujuan pembelajaran, materi, metode pembelajaran dan sumber belajar (Nihlah, 2011). Tujuan pembelajaran merupakan komponen utama yang harus 
dirumuskan dalam pembelajaran, karena merupakan sasaran dari proses pembelajaran. Tujuan pembelajaran dirumuskan dengan mengacu pada rumusan yang terdapat dalam indikator, dalam bentuk pernytaan yang operasional. Dengan demikian, jumlah rumusan tujuan pembelajaran dapat sama atau lebih banyak daripada indikator (Saputri, 2017). Komponen kedua dalam sistem pembelajaran adalah materi. Materi atau isi pembelajaran merupakan inti dalam proses pembelajaran. Materi pembelajaran dapat berupa pengetahuan yang meliputi fakta, konsep, prinsip dan prosedur, berupa keterampilan dan sikap atau nilai. Pemilihan materi harus sesuai dengan tujuan yang hendak dicapai (Nihlah, 2011).

Siswa termotivasi dikarenakan multimedia memuat materi yang dikemas dengan menarik.Kemenarikan tersebut dilihat dari gambar, video dan animasi yang disajikan dalam materi. Gambar, video dan animasi merupakan elemen dalam multimedia, dalam menentukan gambar, video dan animasi yang digunakan dalam multimedia interaktif dapat dipilih "gambar yang mempunyai kaitan erat dengan apa yang akan disampaikan, memilih gambar yang tepat tentunya harus berpedoman kepada materi yang disampaikan, suara dalam multimedia sangat berperan untuk memberikan semangat dalam mengeksplor apa yang ada dalam multimedia tersebut, video lebih efektif menyampaikan pesan, animasi digunakan untuk menyampaikan pesan yang rumit dijelaskan agar mudah dimengerti" (Windu, 2016). Dapat disimpulkan dengan menggunakan multimedia pembelajaran interaktif berorientasi pendidikan karakter dapat membantu guru dalam menyampaikan materi, efisien dalam mencapai tujuan pembelajaran sehingga materi yang diberikan dapat lebih maksimal diterima oleh siswa, dan dapat membantu siswa dalam proses belajar mandiri.

\section{Simpulan}

Berdasarkan rumusan masalah, hasil analisis data dan pembahasan pada penelitian ini, maka dapat diambil simpulan sebagai berikut.Pertama, multimedia pembelajaran interaktif dikembangkan menggunakan tahapan dari model pengembangan Hannafin dan Peck. Tahapan pengembangan produk menggunakan model Hannafin and Peck yaitu penilaian kebutuhan, desain/perancangan dan pengembangan dan implementasi. Kedua, kelayakan hasil pengembangan multimedia pembelajaran interaktif berorientasi pendidikan karakter pada (1) ahli desain pembelajaran berpredikat sangat baik $(90,7 \%)$, (2) ahli isi mata pelajaran berpredikat sangat baik (90\%), (3) ahli media pembelajaran berpredikat sangat baik (96\%), (4) uji coba perorangan berpredikat sangat baik $(93,7 \%)$, (5) uji coba kelompok kecil berpredikat sangat baik (94,0\%), dan (6) uji coba lapangan berpredikat sangat baik $(93,9 \%)$. Ketiga, multimedia pembelajaran interaktif berorientasi pendidikan karakter terbukti efektif secara signifikan dapat meningkatkan hasil belajar Bahasa Bali kelas V semester genap tahun pelajaran 2018/2019 di SD Negeri 1 Angantaka.

\section{Daftar Pustaka}

Agung, A.A. Gede. 2014. Metodologi Penelitian Pendidikan. Buku Ajar Metodologi Penelitian Pendidikan. Singaraja: Undiksha

Koyan, I Wayan. 2012. Statistik Pendidikan “Teknik Analisis Data Kuantitatif”. Singaraja : Universitas Pendidikan Ganesha Press.

Nihlah, N.2011. "Tinjauan Umum Tentang Pembelajaran". Tersedia pada :http://digilib.uinsby.ac.id/9620/5/Bab\%202.pdf (diakses 14 Juni 2019)

Ramadhan, Wisnu.2013. Makalah media Pembelajaran. Tersedia pada:https://www.academia.edu/8875123/Makalah_Media_Pembelajaran (diakses 15 Juni 2018)

Saputri, ATW.2017. "Hakikat Desain Pembelajaran". Terdapat pada :http://repository.uksw.edu/bitstream/123456789/15849/2/T1_292013506_BAB\%20II.pdf (diakses 10 November 2018)

Sudatha, I Gde Wawan dan I Made Tegeh Tegeh.2015. Desain Multimedia Pembelajaran.Yogyakerta: media akademi

Sulistyono.2013.Pengembangan Media Pembelajaran Interaktif Berbasis Flash Pada Standar Kompetensi Mengadministrasi Server Dalam Jaringan Untuk Siswa Smk Kelas XII Kompetensi Keahlian Teknik Komputer Dan Jaringan. Tersedia pada: http://eprints.uny.ac.id/22014/1/08520241016\%20Sulistyonoi.pdf (diakses 15 Juni 2018)

Suparno, Paul. dkk. 2002. Reformasi Pendidikan. Yogyakarta: Penerbit KANSIUS

Tegeh, I Made dan I Made Kirna.2010.Metode Penelitian Pengembangan Pendidikan.Buku Ajar. Singaraja: Undiksha

Tegeh, I Made. dkk. 2014. Model Penelitian Pengembangan. Yogyakarta: GRAHA ILMU

Utami, Budi, dkk. 2009. "Penerapan Pembelajaran Konstruktivisme Dalam Pembelajaran Kimia Di SMU". Malang: Universitas Negeri Malang. Tersedia pada:https://www.researchgate.net/profile/Budi_Utami2/publication/322251826_PENERAPAN_PEMBE 
LAJARAN_KONSTRUKTIVISME_DALAM_PEMBELAJARAN_KIMIA_DI_SMU/links/5a4e3be9ac a2729b7c8e7e55/PENERAPAN-PEMBELAJARAN-KONSTRUKTIVISME-DALAM-

PEMBELAJARAN-KIMIA-DI-SMU.pdf?origin=publication_detail (diakses 15 Juni 2018)

Windu, Ida Bagus Kt. Trina. dkk.2016. "Multimedia Interaktif Untuk Proses Pembelajaran. Denpasar: ISI Denpasar. Volume 19., No.21.2016. Tersedia pada: https://jurnal.isidps.ac.id/index.php/prabangkara/article/view/135/75 (diakses 10 November 2018) 